This item was submitted to Loughborough's Research Repository by the author.

Items in Figshare are protected by copyright, with all rights reserved, unless otherwise indicated.

\title{
Design for occupational safety and health: Key attributes for organisational capability
}

PLEASE CITE THE PUBLISHED VERSION

https://doi.org/10.1108/ECAM-09-2018-0389

PUBLISHER

Emerald

VERSION

AM (Accepted Manuscript)

\section{PUBLISHER STATEMENT}

This paper was accepted for publication in the journal Construction and Architectural Management and the definitive published version is available at https://doi.org/10.1108/ECAM-09-2018-0389.

\section{LICENCE}

CC BY-NC-ND 4.0

\section{REPOSITORY RECORD}

Manu, Patrick, Anush Poghosyan, Abdul-Majeed Mahamadu, Lamine Mahdjoubi, Alistair Gibb, Michael Behm, and Olugbenga Akinade. 2019. "Design for Occupational Safety and Health: Key Attributes for Organisational Capability”. figshare. https://hdl.handle.net/2134/37099. 


\title{
Engineering Construction and Architectural Management
}

\author{
DOI: 10.1108/ECAM-09-2018-0389
}

\section{Design for Occupational Safety and Health: Key Attributes for Organisational Capability}

\author{
Patrick Manu ${ }^{1 *}$, Anush Poghosyan ${ }^{1}$, Abdul-Majeed Mahamadu ${ }^{2}$, Lamine Mahdjoubi², \\ Alistair Gibb ${ }^{3}$, Michael Behm ${ }^{4}$ and Olugbenga Akinade ${ }^{5}$ \\ ${ }^{1}$ School of Mechanical, Aerospace and Civil Engineering, The University of Manchester, \\ Manchester, United Kingdom. \\ ${ }^{2}$ Faculty of Environment and Technology, University of the West of England, Bristol, United \\ Kingdom. \\ 3 School of Architecture, Civil and Building Engineering, Loughborough University, \\ Loughborough, United Kingdom. \\ ${ }^{4}$ College of Engineering and Technology, East Carolina University, Greenville, North \\ Carolina, USA. \\ ${ }^{5}$ Bristol Business School, University of the West of England, Bristol, United Kingdom.
}

\section{Acknowledgement}

This research was funded by The United Kingdom Engineering and Physical Sciences Research Council (Grant numbers: EP/N033213/1 and EP/N033213/2). The contribution of the following industry partner organisations is acknowledged: Heathrow Airport, Mott MacDonald, Bam Construction Limited, ISG Construction Limited, Nick Bell Risk Consultancy, GCP Architects, and Safety in Design. Appreciation is also extended to the professionals who participated in the study. 


\begin{abstract}
Purpose: Against the backdrop of the contribution of design to the occurrence of occupational injuries and illnesses in construction, design for occupational safety and health (DfOSH) is increasingly becoming prominent in the construction sector. To ensure that design interventions are safe for construction workers to build and maintain, design firms need to have the appropriate organisational capability in respect of DfOSH. However, empirical insight regarding the attributes that constitute DfOSH organisational capability is lacking. This study, which trailblazes the subject of DfOSH organisational capability in construction, addresses two key questions: (1) what organisational attributes determine DfOSH capability; and (2) what is the relative priority of the capability attributes?
\end{abstract}

Design/methodology/approach: The study employed three iterations of expert focus group discussion and a subsequent three-round Delphi technique accompanied by the application of voting analytical hierarchy process (VAHP).

Findings: The study revealed 18 capability attributes nested within six categories namely: competence (the competence of organisation's design staff); strategy (the consideration of DfOSH in organisation's vision as well as the top management commitment); corporate experience (organisation's experience in implementing DfOSH on projects); systems (systems, processes and procedures required for implementing DfOSH); infrastructure (physical, and information and communication technology (ICT) resources); and collaboration (inter and intra organisational collaboration to implement DfOSH on projects). Whilst these categories and their nested attributes carry varying weights of importance, collectively, the competence related attributes are the most important, followed by strategy.

Originality/value: The findings should enable design firms and other key industry stakeholders (such as the clients who appoint them) to understand designers' DfOSH capability better. Additionally, design firms should be able to prioritise efforts/investment to enhance their DfOSH capability.

Keywords: design; construction; construction safety. 


\section{Introduction}

In many countries, the construction sector has earned the unenviable rank of being amongst the topmost contributors to occupational fatalities, injuries and illnesses (see Bureau of Labor Statistics, 2018; Health and Safety Executive (HSE), 2018). Over the years, this has triggered a plethora of efforts to reduce accidents, injuries and illnesses in construction. Amongst the initiatives in this direction is design for occupational safety and health (DfOSH) due to the contributory role design plays in construction accident causation (Gibb et al., 2014). In line with DfOSH, design firms (or more broadly organisations with design responsibilities) are expected to produce inherently safer designs for construction, maintenance and the use of built assets. However, such organisations would have varying capability in respect of DfOSH implementation. Furthermore, empirical insight into what constitutes DfOSH capability in construction is non-existent (Manu et al., 2017), implying a lack of clarity regarding the assessment/determination of DfOSH capability of organisations with design responsibility on projects, e.g. architectural and engineering design firms, and design and build contractors. In response to this knowledge gap, this study addresses two key questions: (1) what organisational attributes determine DfOSH capability; and (2) what is the relative priority of the capability attributes? The paper commences with a review of the relevant literature, which presents an outlook of the occupational safety and health $(\mathrm{OSH})$ performance of the construction sector. While highlighting the contribution of design to the OSH performance, it discusses DfOSH, the research gaps relating to DfOSH capability, and then presents the argument for research to address the gaps. Subsequently, the research methods applied are presented, followed by the results, discussion of the results and conclusions.

\section{Literature Review}

\section{The occupational safety and health performance of the construction sector}

In many countries, the construction sector accounts for an alarming number of fatalities, injuries and illnesses. For instance, in the United States of America (USA) the construction sector accounted for the highest number of occupational deaths (i.e. 971 out of a total fatal work injuries of 5,147) in 2017 (Bureau of Labor Statistics, 2018). In the United Kingdom (UK), for over 30 decades (i.e. 1981 to 2017/18) the rate of occupational fatal injury to workers in the construction sector has consistently been greater than the rate of occupational fatal injury to workers in all industries, and in 2017/18 the rate for construction was around four times the rate for all industries (Health and Safety Executive (HSE), 2018). These occupational tragedies have significant socio-economic cost implications. For instance, in the USA, based on 2002 national incidence data from the Bureau of Labor Statistics, the costs of non-fatal and fatal injuries in the construction industry (in 2002) were estimated at US\$11.5 billion (Waehrer et al., 2007). In the UK, the HSE (2014) estimated that "injuries and new cases of ill health resulting largely from current working conditions in workers in construction cost society over GB $£ 1.1$ billion (circa US\$1.7 billion*) a year”. Clearly, there is an urgency to improve OSH in the construction industry.

Efforts to address the OSH problem in construction have been wide-ranging, including studies that have investigated the factors responsible for construction accidents. From these studies, it is understood that accident causation in construction is a complex and multi-faceted phenomenon due to the varying complexity, dynamism and transient nature of construction works. Despite this complexity, two broad factors are often at play in the causation of

\footnotetext{
${ }^{*}$ Note: US\$1 = GP£ 0.631. Exchange rates are average 2012 interbank exchange rates. See https://www.oanda.com/currency/average
} 
construction accidents: proximate/proximal factors, which are site-based; and underlying factors, which usually emanate from the pre-construction stage (Gibb et al., 2006; Manu et al., 2014). It is understood that the proximate factors are triggered by the underlying factors, which are subtle (but potent) and distant in time and/or space from the incidents (Haslam et al., 2005; Manu et al., 2012). Removing or mitigating underlying factors is thus important in addressing accidents in construction. The need to attend to underlying causal factors is also buttressed by the fact that the pre-construction stage from which they emanate offers project participants a great opportunity to influence OSH on projects. Consequently, prominent amongst the efforts to improve construction OSH has been the emphasis on pre-construction OSH planning and risk management to mitigate significant underlying causes of occupational accidents such as design (Gambatese et al., 1997; Behm, 2012; Tymvious and Gambatese, 2016).

\section{Design for occupational safety and health in construction}

The contribution of design to construction accidents is well established (Haslam et al., 2005; Behm, 2005). In the study by Haslam et al. (2005), it was argued that causal links could be demonstrated between permanent works design and close to $30 \%$ of the 100 accidents that were examined. Furthermore, up to $50 \%$ of the 100 accidents that were examined could have been mitigated through a design change. In the study by Behm (2005), 42\% of 224 construction fatality cases were linked to design (Behm, 2005). In a more recent study by Manu et al. (2014) involving a survey of 184 UK construction practitioners, complex design (i.e. design with intricate aesthetic qualities) was perceived by the practitioners to have a high potential to influence the occurrence of construction accidents. In addition the contribution of design to accidents resulting in injuries and deaths, there is a growing recognition that design decisions also have a major influence on the occurrence of health hazards in construction (e.g. noise, skin irritants, vibration, dust, and respirable crystalline silica) that can lead to illnesses such as dermatitis, hearing loss, hand-arm vibration syndrome and respiratory illnesses (Skan, 2015). The contribution of design to the occurrence of construction accidents and health hazards has therefore given rise to the concept and practice of "design for occupational safety and health (DfOSH)" in construction which is also referred to as "prevention through design" (especially in the USA), and "safety in design".

The concept of DfOSH or prevention through design is broad (not limited to construction works alone) and could encapsulate anticipating and "designing out" potential OSH risks associated with a process, structure, equipment, tool, and product (Schulte et al., 2008). However, in construction, the concept has commonly been used with a focus on anticipating and "designing out" (i.e. eliminating or reducing via design decision/consideration) OSH risks associated with a building structure, civil engineering structure or engineering construction structure (HSE, 2015) and usually does not cover design of a process, product, equipment or tool which is usually undertaken by product manufacturers. The term design has also been used to include drawings, design details, and specifications relating to a building structure, civil engineering structure or engineering construction structure (HSE, 2015). DfOSH in construction thus requires that designers (e.g. architects and engineers) give careful consideration to how design decisions would affect the OSH of builders/constructors and maintenance workers. DfOSH in construction is increasingly gaining ground in several geographic contexts (e.g. USA, Australia, Singapore, and Europe) and in some countries, it is mandated by OSH law (e.g. the Workplace Safety and Health (Design for Safety) Regulations 2015 of Singapore, the Work Health and Safety Acts and Regulations of several Jurisdictions in Australia, and the adaption of European Council Directive 92/57/EEC on temporary or mobile construction sites in several countries in Europe (Aires et al., 2010). In the UK, the Construction Design and Management Regulations (latest version: CDM 2015) have been a powerful stimulus since the mid-1990s to 
the prominence of DfOSH in the construction industry. Additionally, under CDM 2015, the appointment of design firms (or firms with design responsibilities) requires due diligence by appointers in ensuring that these firms have the appropriate organisational capability, which encompasses the policies, systems, resources and personnel of the organisation in order to fulfil their design role in a manner that secures OSH (HSE, 2015). Firms being appointed into design roles must similarly ensure that they have the appropriate organisational capability. In other countries such as some European countries where the European Directive 92/57/EEC has been adapted, there are similar legislative requirements regarding ascertaining the competence and suitability of designers in respect of DfOSH. For example, Regulation 7 of the Safety, Health and Welfare at Work (Construction) Regulations 2013 of Ireland stipulates duties to ascertain the suitability of designers. This brings to the fore an important issue of organisations with design responsibilities having adequate DfOSH capability. However, regardless of DfOSH regulations, the fundamental drive to reduce accidents, injuries and illnesses in construction implies that, if design is a contributor to accidents, injuries and illnesses then it is imperative that design organisations have adequate DfOSH capability.

Within the past two decades and beyond, there has been a growing body of research on DfOSH in construction (e.g. Gambatese et al. (1997), Behm (2012), and Tymvious and Gambatese (2016), to highlight the durational spread of journal articles in the domain). Commenting on the growing number of studies on DfOSH in construction, Öney-Yazıc1 and Dulaimi (2015) observe that publications have often focussed on: (1) policies and regulations implemented in different parts of the world regarding accident prevention through design (e.g. Aires et al., 2010); (2) developing measures, procedures, design suggestions, and tools for use by designers (e.g. Hadikusumo and Rowlinson, 2004); and (3) integration of safety into the design process of construction projects (e.g. Saurin and Formoso, 2008). Beyond these, some studies have also focussed on issues regarding designers' OSH knowledge and education (e.g. Behm et al., 2014). However, within the extant DfOSH literature, empirical insight regarding what constitutes DfOSH organisational capability in construction is lacking (Manu et al., 2017). Consequently, there is currently a dearth of systematic approaches for ascertaining the DfOSH capability of construction organisations with design responsibilities to pave way for improvement in DfOSH capability. This is evident from the limitations of existing OSH capability assessment schemes (e.g. the British Standards Institute (2013), Publicly Available Specification (PAS) 91:2013), viz., the absence of: a thorough indication of what constitute DfOSH capability attributes; and the relative weights of the attributes. Such insights are crucial to enable design firms to ascertain their DfOSH capability and for construction clients who appoint design firms to be able make appointments based on the DfOSH capability of design firms or organisations with design responsibilities on projects. Given the significance of DfOSH in addressing the established contributory role of design to the occurrence of accidents, injuries and health hazards, it is imperative that research is undertaken to provide empirical realities on the knowledge gaps regarding DfOSH capability. The following section presents the research methods applied to address the knowledge gaps.

\section{Research Method}

Given the paucity of empirical work on the subject of DfOSH organisational capability, there is no clear research-based insight regarding DfOSH organisational capability attributes. In such a situation, a qualitative inquiry is suitable given the absence of a rich literature base from which speculations or prior formulations can be made about the subject of inquiry (Fellows and Lui, 2008). In view of this, expert group techniques were deemed most appropriate to elicit the relevant DfOSH capability attributes and to ascertain their relative priorities. In particular, expert focus group discussion (FGD) (brainstorming approach) (Tomlison, 1994), and the 
Delphi technique (Hallowell and Gambatese, 2010) were combined sequentially. Expert group methods are increasingly being used in built environment research and other fields for elicitation of knowledge and identification of priorities, when there is incomplete/limited knowledge about a problem or phenomena (Ameyaw et al., 2016). While the expert FGD enabled elicitation of the capability attributes, the Delphi technique (combined with a multicriteria decision-making method - voting analytic hierarchy process) enabled prioritisation of the attributes in order to address the aforementioned two research questions. Figure 1 gives an overview of the key phases of the empirical aspect of the research.

\section{[Insert Figure 1]}

\section{Expert focus group (brainstorming approach)}

Iterations of expert focus group discussion (FGD) with experienced construction professionals were undertaken. The purpose was to draw on participant's DfOSH experience and expertise in order to generate a list of organisational attributes that determine DfOSH capability. Following the guidance of Hallowell and Gambatese (2010) regarding the criteria for selecting experts (e.g. a professional with expertise in the subject of inquiry, and a minimum of five years of experience), invitations were sent to $11 \mathrm{UK}$ organisations (including clients, design firms, construction firms, OSH consultancies, and OSH regulator) for them to nominate experienced construction professionals who would contribute to the research. Nine organisations accepted the invitation to contribute to the study. From the nine organisations, eight experts were engaged in three iterations of FGD sessions over a 10-month duration.

Each of the three FGD sessions lasted approximately two hours. The FGDs mainly involved brainstorming exercises and reviews aimed at: identifying attributes that determine DfOSH capability; refining the attributes; and identifying indicators or examples of evidence for the attributes. From the brainstorming activities, the thoughts of the experts regarding the capability attributes were recorded via note-taking on open-ended feedback forms. The recorded thoughts were collated and used in describing $18 \mathrm{DfOSH}$ organisational capability attributes that were subsequently categorised, based on their relatedness, into six thematic areas of DfOSH organisational capability. The six thematic categories are: competence; strategy; corporate experience; systems; infrastructure; and collaboration. One of the 18 attributes (i.e. "corporate experience") constituted a category of its own, as it could not be rationally clustered with other attributes. The three iterations of the FGD sessions were useful in enabling reviewing (by the experts), and subsequent refining and re-wording of the capability attributes and their thematic categorisation to ensure their validity, ease of understanding and applicability in industry. The iterations thus provided a layer of credibility check which is similar to member checking (Creswell, 2009), whereby research participants are allowed to review research findings as part of ensuring credibility in qualitative research (Creswell, 2009). Detailed descriptions of the thematic categories and the attributes are presented in the results section. The categories and the attributes within them were subsequently applied in a Delphi technique.

\section{Delphi}

The Delphi method is an iterative process used to collect and distil the judgments of experts using a series of questionnaires interspersed with feedback (Skulmoski et al., 2007). The method has four key features: anonymity, iteration, controlled feedback, and the statistical aggregation of group response (Hallowell and Gambatese, 2010). The process stops when consensus or saturation (i.e. point where sufficient information has been exchanged) is reached 
(Skulmoski et al., 2007). In this study, the Delphi method was used to establish the relative priorities of the DfOSH capability attributes through the use of the collective intelligence of construction professionals with expertise in $\mathrm{OSH}, \mathrm{DfOSH}$, and selection of design firms, which under CDM 2015 require consideration of organisational capability in respect of OSH.

\section{Implementing the Delphi method}

Table 1 shows the main features of the Delphi method as applied in this research. Similar to the FGDs, purposive sampling (based on expertise criteria) was used in recruiting participants for the Delphi study. The purposively sampling was supplemented by snowballing whereby experts who were invited by the researchers, subsequently invited other experts within their professional network. An online expert panel registration form was set up and a link to the form was sent in an invitation to industry professionals, and professional groups that are relevant to the study (e.g. LinkedIn groups for RIBA and ICE). From the invitations, 38 experts registered interest in participating in the Delphi study and 28 to 32 participated in the Delphi rounds.

Three rounds of Delphi interspersed with feedback were undertaken. The DfOSH capability attributes and the thematic categories were incorporated in a questionnaire. In the first round, the questionnaire requested the experts to rank the six thematic categories based on their level of importance to the practise of DfOSH. Similarly, the participants were asked to rank the attributes within each of the categories.

In the second round, the median ranks for the six categories and the attributes within each category were incorporated in the round one questionnaire. Additionally, the questionnaire was customised for each expert by the inclusion of the expert's own round one responses. The experts were asked to reflect on the information (i.e. their responses and the median ranks) to rank the attributes again. At the end of the round, agreement analysis using Kendall's coefficient of concordance $(W)$ was undertaken to determine the degree of consensus among the experts in their ranking of the atttibutes. The coefficient can be calculated using the equation below (Siegel and Castellan Jr., 1988, Braimah, 2008), and it ranges from zero (which indicates no agreement) to one (which indicates perfect agreement). As the coefficient of concordance approachs one, the greater the degree of consensus. IBM SPSS Statistics version 23 was used to determine Kendall's $W$ and the level of significance. The conventional statistical significance level of $p=0.05$ was adopted (Field, 2013). The agreement analysis showed that significant consensus had been attained for the ranking of the six categories as well as the ranking of attributes within the "competence", "strategy" and "systems" categories. There was not significant consensus for the ranking of the attributes within the "infrastructure" and "collaboration" categories. Consequently, only these two categories were taken forward in a third round.

Eq. 1

$$
W=\frac{12 \sum R i^{2}-3 k^{2} N(N+1)^{2}}{k^{2} N\left(N^{2}-1\right)-k \sum T_{j}} ; \text { where }
$$

$\sum R i^{2}$ sum of the squared sums of ranks for each of the $N$ objects being ranked;

$k$ is the number of sets of rankings i.e. the number of respondents; and

$T j$ is the correction factor required for the $j$ th set of ranks for tied observations given by

$T j=\sum_{i=1}^{g_{j}}\left(t_{i}^{3}-t_{i}\right)$, where $t_{i}$ is the number of tied ranks in the $i$ th grouping of ties, and $g_{j}$ is the number of groups of ties in the $j$ th set of ranks. 
In the third round, the median ranks for the attributes within the "infrastructure" and "collaboration" categories were incorporated in a questionnaire. Once again, the questionnaire was customised for each expert by the inclusion of each expert's own round two responses. The experts where asked to reflect on this information in order to rank the attributes again. At the end of the round, agreement analysis using Kendall's $W$ still showed that consensus had not been attained. However, following the recommendation by Hallowell and Gambatese (2010) regarding the use of three Delphi rounds, and the suggestion by Dalkey et al. (1970) that Delphi results are most accurate after round two but become less accurate with additional rounds, in this study the Delphi process was terminated after the third round. Furthermore, a check for saturation using Wilcoxon signed rank test (conducted using IBM SPSS Statistics version 23) showed that there was no significant difference between the round two and round three responses for the attributes within the "infrastructure" and "collaboration" categories. The results of the agreement analysis and the Wilcoxon signed rank test are presented in the results section.

\section{Voting analytical hierarchy process}

The analytic hierarchy process (AHP) developed by Saaty (1980) is a multi-criteria decision method used to facilitate decisions that involve multiple competing criteria. It quantifies the relative priorities/weights of a given set of criteria based on the judgment of the decisionmakers/experts through a pair-wise comparison of the criteria. AHP has been widely applied in several fields of research including construction engineering and management (CEM) (Ameyaw et al., 2016), thus indicating its usefulness as a multi-criteria decision method. AHP has also commonly been applied in conjunction with the Delphi method in CEM research (Ameyaw et al., 2016). Despite its utility, AHP has some limitations that led to the advent of the voting analytic hierarchy process (VAHP) by Liu and Hai (2005). Prominent amongst the limitations of AHP is the difficulty in applying the paired comparison (Liu and Hai, 2005), particularly where the criteria are many (Hadi-Vencheh and Niazi-Motlagh, 2011). VAHP, instead of using paired-comparison, adopts a vote ranking approach whereby a set of criteria and sub-criteria in a hierarchical structure is ranked to determine their weights (Liu and Hai, 2005). Given the large number of DfOSH capability attributes in this study, the VAHP approach was deemed more appropriate. Additionally, the thematic categorisation of the attributes constituted a hierarchical structure, which lends itself to the use of VAHP.

\section{Implementation of VAHP}

The use of VAHP in this study involved a six-step process adapted from Liu and Hai's (2005) steps for implementing VAHP. The six steps are as follows:

Step 1- Selection of criteria: In the case of this study the six thematic categories of DfOSH capability attributes constituted the criteria.

Step 2- Structure the hierarchy of the criteria: $17 \mathrm{DfOSH}$ attributes (excluding "corporate experience") constituted the sub-criteria within the six thematic categories. As previously mentioned "corporate experience" constituted a thematic category of its own.

Step 3-Prioritise the criteria: From the round two Delphi, 30 experts ranked the six categories of attributes.

Step 4-Prioritise the sub-criteria: From the round two Delphi, 30 experts ranked the attributes within the "competence", "systems" and "strategy" categories. From the round three Delphi, 
28 experts ranked the attributes within the "infrastructure" and "collaboration" categories as only these two categories were carried forward to the third round of the Delphi process.

Step 5- Calculate the weights of criteria and sub-criteria: The equation proposed by HadiVencheh and Niazi-Motlagh (2011) for determining criteria weights was applied based on the six thematic category of attributes and the number of attributes within each category. The equation is given by:

Eq. 2

$$
\begin{aligned}
& w_{1} \geq 2 w_{2} \geq \cdots \geq S w_{s} \geq 0 \\
& \sum_{S=1}^{S} w_{S}=1 ;
\end{aligned}
$$

where $w$ is a coefficient weight applied to the vote ranking of each criterion to determine the criterion weight, and $s$ is the number of positions, thus $w_{s}$ is the coefficient weight for the sth position. For example, for three criteria being ranked, $w_{l}$ is the coefficient weight for the $1^{\text {st }}$ position, $w_{2}$ is the coefficient weight for the $2^{\text {nd }}$ position, and $w_{3}$ is the coefficient weight for the 3rd position.

Based on the above equation, the coefficient weights for the relevant number of criteria/subcriteria were determined (see Table 2). The coefficient weights were then applied to the ranking data from the Delphi round 2 and 3 to obtain the weights of the six categories of attributes (i.e. criteria) and the weights of the attributes within each category (i.e. sub-criteria). For example, in the round 3 Delphi (which involved 28 experts), for the infrastructure category, physical work resources was ranked $1^{\text {st }}$ by 18 experts and $2^{\text {nd }}$ by 10 experts. ICT resources was ranked $1^{\text {st }}$ by 12 experts and $2^{\text {nd }}$ by 16 experts. The weights for these attributes are determined as follows:

- $\quad$ Physical work resources $=(18 \times 0.6667)+(10 \times 0.3333)=15.3336$

- $\quad$ ICT resources $=(12 \times 0.6667)+(16 \times 0.3333)=13.3332$

Subsequent to the calculation of weights, the obtained weights for the categories were normalised so that they add up to one. Similarly, the obtained weights for the attributes in each category were normalised.

Step 6-Calculate the global weights of sub-criteria: The final stage in VAHP is to obtain the global (i.e. overall) weight of sub-criteria. This is achieved by multiplying the normalised weight of a criterion by the normalised weight of its corresponding sub-criteria. The overall outcomes of the VAHP are presented in the results section.

[Insert Table 1]

[Insert Table 2]

\section{Demographic profile of experts}

The demographic profile of the FGD experts is shown by Table 3 and that for the Delphi experts is shown by Table 4. For the FGD experts, the minimum years of experience in professional role (in relation to design, DfOSH, OSH management and/or selection of design firms) and the minimum years of experience in construction are 10 and 15 respectively. Similarly, for the Delphi experts, the minimum years of experience in professional role and in construction are 
6.5 and 10 respectively. Overall, the experts are suitable as their roles and experience revolved around design, DfOSH, OSH management, and selection of project organisations, particularly design firms, which under the UK CDM 2015 regulations requires consideration of organisations capability in respect of OSH. Altogether, the experts were thus well placed to offer credible information regarding the subject of inquiry.

\section{[Insert Table 3]}

[Insert Table 4]

\section{Results}

The results are structured into three main headings: results of FGDs; results of the Delphi; and results of the VAHP.

\section{Results of expert FGDs}

Table 5 presents a detailed description of the DfOSH capability attributes and their thematic groups. The "competence" thematic group, which encapsulates the competence of organisation's design staff in respect of DfOSH, contained the highest number of attributes (i.e. six). These are: skills of design staff; knowledge of design staff; experience of design staff; design staff access to competent advice; recruitment of design staff into appropriate roles and clarity of roles; and continuous professional development (CPD) training for design staff. After "competence", the "systems" and "strategy" categories contain four and three capability attributes respectively. The systems-related attributes refer to the organisation's systems, processes and procedures that are required for the implementation of DfOSH. The strategyrelated attributes refer to attributes that demonstrate the consideration of DfOSH in organisation's vision as well as the top management commitment for DfOSH. The "infrastructure" cluster of attributes relate to an organisation's physical and ICT resources required for DfOSH, while the "collaboration" cluster refers to the ability of various design units within an organisation to collaborate to implement DfOSH, as well as the ability of the organisation (as a unit) to collaborate with other organisations to implement DfOSH on projects. Both thematic clusters had two attributes within them. Corporate experience, referring to an organisation's experience in implementing DfOSH on projects, was a stand-alone attribute. For all the attributes, examples of indicators that can be used to evidence or assess performance or capability maturity were also elicited from the FGDs. These indicators are shown in Table 5. For example, the CPD records of design staff could give an indication of the maturity or performance of a design firm in relation the provision of DfOSH CPD training for their design staff.

\section{Results of the Delphi process}

The results of the three-round Delphi process are summarised by Table 6 . The number of participants in the rounds are: 32 for round one; 30 for round two; and 28 for round three. Across the three rounds there were no changes in the medians except for "strategy" and "corporate experience" whose medians changed from 3 (in round one) to 2.5 (in round two). However, in terms of the ranking of thematic categories and attributes (based on the medians), there was consistency throughout the rounds. The Kendall's Coefficient of Concordance $(W)$ values obtained for the ranking of the thematic categories show that there was significant consensus in the experts' ranking at round one and round two. Similarly, at round one and round two there was significant consensus in the experts' ranking of the competence-related attributes, systems-related attributes and strategy-related attributes. Furthermore, there was improvement in the consensus between the two rounds as shown by the increase in the 
Kendall's Coefficient of Concordance $(W)$ values. Whilst there was improvement in the Kendall's $W$ for the ranking of the infrastructure-related attributes and the collaboration attributes between the round one and two, the Kendall's $W$ values were not significant, thus necessitating a third round. At round three, the Kendall's $W$ was still not significant, and it was also lower than that for round two. Furthermore, the Wilcoxon signed rank test, which was used to check for saturation, yielded insignificant results as shown by Table 7 . The test shows that there was not a significant difference in the ranking between round two and round three for the "infrastructure" and "collaboration" attributes. This implied that saturation had been reached.

\title{
Results of the VAHP
}

Tables 8 and 9 show the outcomes of the VAHP. Regarding the thematic grouping of the attributes (shown by Table 8), "competence", is the most important followed by "strategy". Collectively, these two categories account for $52.62 \%$ of the weights of the six categories. "Infrastructure" is the least important and immediately above it is "systems". "Collaboration is ranked $4^{\text {th }}$ above "systems". An examination of the attributes within the thematic categories shows that for the competence related attributes, skills, knowledge and experience of design staff collectively account for over $70.14 \%$ of the category weight. Top management commitment to DfOSH, which accounts for approximately $50 \%$ of the category weight, is the most important strategy-related attribute. For systems related attributes, "design risk management", is the most important attribute followed by "project review". Collectively, these two account for $66.37 \%$ of the category weight. Regarding infrastructure related attributes, "physical work resources", which accounts for $53.49 \%$ of the category weight, is the most important attribute. "Inter-organisational collaboration" emerged as the most important attribute of the two collaboration attributes.

Based on the global weights (shown by Table 9), "corporate experience" emerges as the most important attribute, followed by "top management commitment". This is also followed by design staff experience, design staff knowledge, and design staff experience in that sequence. Collectively, these five attributes account for approximately $51 \%$ of the global weights. An inclusion of the next set of four attributes (i.e. "intra-organisational collaboration", "interorganisational collaboration", "design risk management", and "policy") increases the percentage to $72 \%$, thus indicating that nine out of the 18 attributes (i.e. a half) account for over $70 \%$ of the global weights.

\author{
[Insert Table 4] \\ [Insert Table 5] \\ [Insert Table 6] \\ [Insert Table 7] \\ [Insert Table 8] \\ [Insert Table 9]
}

\section{Discussion}

In this section, the findings are reviewed and interpreted in the light of existing literature on DfOSH and capability maturity concepts. The categorisation of the proposed DfOSH attributes is consistent with the conventional notion of organisational capability maturity, albeit specific 
to DfOSH. Hence, the DfOSH capability attributes align broadly with key process areas commonly adopted in capability maturity models, namely: people (which is aligned to the "competence" and "collaboration" clusters); policy (which is aligned to the "strategy" cluster); process (which is aligned to the "systems" cluster); and technology (which is aligned to the "infrastructure" cluster) (Succar, 2009; Software Engineering Institute, 2011). Furthermore, attribute definitions align with Strutt et al.'s (2006) proposed three-stage categorisation of design for safety and environment for offshore facilities, namely: "formal safety demonstration", "safety implementation" and "long-term investment in safety". Based on Strutt et al.'s (2006) definitions, "formal safety demonstration" refers to the existence of systems and strategy within an organisation to ensure designs meet predefined acceptance criteria based on protocols and standards as well as sound risk assessments. The "safety implementation" category refers to the coordination of resources and supply chain, and the implementation of standards to achieve safety. The "long-term investment in safety" encapsulates the management of competence, research and development, and organisational learning to sustain performance and continuous improvement. Despite some similarities in attribute definitions, Strutt et al.'s (2006) model focuses on safety and environmental performance as well as design for internal process maturity with less emphasis on historical indicators of organisational capability such as experience (i.e. both individual and corporate), which features prominently in the DfOSH capability attributes found in this study.

While some of the DfOSH capability attributes align with common features of organisational capability (e.g. leadership, physical resource availability, and human resources (Succar, 2009; Software Engineering Institute, 2011)), others also relate specifically to DfOSH (e.g. design quality management and design risk management) and thus have not been previously considered in the safety capability maturity models currently available (e.g. HSE, 2000; Foster and Hoult, 2013). Furthermore, it is acknowledged that features of design, particularly unconventional features, can introduce high OSH risks (Manu et al., 2014) and thus require skills for identification and mitigation of such risks.

The DfOSH capability attributes, particularly, "information communication technology" reflect current industry developments, which emphasise the need for the application of digital and virtual technologies for DfOSH (Teo et al., 2016). Like Strutt et al. (2006), the DfOSH attributes acknowledge the relevance of research and innovation, with a topical example being design for manufacture and assembly (DfMA) (Jensen, 2015). While this supports the notion that increased adoption of manufacturing systems within construction could lead to improved on-site OSH management (Court et al., 2009), it further recognises the need for capacity among designers to be able to DfMA while recognising its OSH benefits as well as risks emanating from its unconventionality.

Regarding attribute importance, the "Infrastructure" cluster of attributes emerged as the least important cluster. This is in sync with the view that knowledge and intellectual assets drive other aspects of organisational performance so far as DfOSH is concerned (Hallowell and Hansen, 2016). Several technological artefacts have emerged including building information modelling (BIM) tools for virtual prototyping and safety risk assessments (Teo et al., 2016; Martínez-Airesa et al., 2018). Other technology-driven tools have been developed as decision support for DfOSH (Ku and Mills, 2010). Despite the acknowledgement of the relevance of these tools for DfOSH (Gambatese et al., 2005), the findings indicate that they are relatively less important in comparison with design staff competence and organisational strategy. This is in accord with Hallowell and Hansen's (2016) view that such tools must be viewed as complements of DfOSH competence rather than panacea. In consonance with views in existing 
studies (Behm et al., 2014), the "competence" category, emerged as the most important category followed by "strategy", and collectively these two account for more than $50 \%$ of the priority weights of all the DfOSH capability attribute categories. The competence category encapsulates design staff skills, knowledge, experience as well as the conditions for the acquisition and maintenance of such competencies, e.g. training. The emergence of competence as the most important capability attribute category is thus unsurprising in view of the recognition of OSH skills, knowledge, attitude and experience as important cornerstones of OSH management (Behm et al., 2014; HSE, 2015). According to Gambatese et al. (2005), these aspects of competence include risk identification skills as well as construction knowledge and experience. A major concern, however, remains the empirical evidence pointing to insufficient DfOSH knowledge and skills among several designers during education (Gambatese et al., 2005; López-Arquillos et al., 2015). While this study highlights the need for training and education in the acquisition of DfOSH knowledge and skills, it emphasises DfOSH experience as the most important attribute within the competence category. This emphasis is noteworthy given that previous studies have reported that mere incorporation of DfOSH principles into designers' education does not result in the levels of competence desirable for DfOSH in practice (Toh et al., 2016). Whereas competence of individuals is generally viewed as a building block to wider organisational capability, this study highlights the relative importance of experience. This is in accord with empirical evidence from previous studies, which have found that designers with construction experience are more likely to recognise OSH hazards in designs as compared to their counterparts with limited construction experience (Hallowell and Hansen, 2016; Hayne et al., 2017). Furthermore, organisation's experience (i.e. corporate experience) in implementing DfOSH on projects emerged as the most important single attribute.

According to the UK's Construction Industry Training Board (CITB) (2014), individual competence is rendered ineffective when the wider organisational strategies of development are non-existent. This brings to the fore the significance of organisational leadership to organisational capability. In this study, the "strategy" category encapsulates an organisation's vision as well as the top management commitment to DfOSH. In several OSH studies, management commitment has also emerged as being paramount to OSH management and performance (Zaira and Hadikusumo, 2017).

The inter-organisational complexity of the construction sector and its potential negative impact on OSH management (e.g. the impact of subcontracting and procurement routes (Manu et al., 2010 ; 2014)) is also evident from the findings; thus, the emergence of collaboration as a relevant capability attribute for DfOSH. Collaborative ethos amongst design firms, including internal collaboration and more so collaboration with organisations in the construction delivery process, is regarded as one of the important DfOSH capability attributes. Collaboration has similarly been recognised as being important to development of safety culture (HSE, 2000). This also highlights the growing recognition of procurement routes that support integration and collaboration for achieving project performance (Mahamadu et al., 2015). Furthermore, it highlights the role of collaboration in facilitating the relevant knowledge exchanges that enrich designers' decision-making capability (CITB, 2014; Hallowell and Hansen, 2016). In relation to DfOSH, that could facilitate effective information and knowledge transfer as well as documentation of lessons learned for future designs.

\section{Conclusion}

This study, through multiple iterations of data gathering from construction industry experts, has addressed significant research gaps relating to DfOSH organisational capability by answering two key questions: (1) what organisational attributes determine DfOSH capability; 
and (2) what is the relative priority of the capability attributes? This study has revealed that DfOSH capability is composed of 18 distinct capability attributes nested within six categories namely: competence (i.e. the competence of an organisation's design staff in respect of implementing DfOSH); strategy (i.e. the consideration of DfOSH in organisation's vision as well as the top management commitment); corporate experience (i.e. an organisation's experience in implementing DfOSH on projects); systems (i.e. systems, processes and procedures required for implementing DfOSH); infrastructure (i.e. physical and ICT resources required for $\mathrm{DfOSH}$ ); and collaboration (i.e. inter and intra organisational collaboration to implement DfOSH on projects). The study further highlights the superiority of the competence category (which features prominently DfOSH experience, knowledge and skill of design staff) and the strategy category (which features prominently top management commitment to DfOSH). The key implications of the research are given below.

\section{Implications for practice}

The main implications of the findings are three-fold: DfOSH capability development/improvement; pre-qualification; and policy. These are elaborated as follows.

\section{DfOSH capability development/improvement}

- The capability attributes and their priority weights should enable design firms to selfexamine their DfOSH capability. This would enable design firms to ascertain the areas of strength and deficiency in respect of their capability.

- Aligned to the above point, on the basis of DfOSH capability self-assessment, design firms could subsequently prioritise investments or efforts targeted at addressing the areas of capability deficiency.

\section{Pre-qualification}

- Clients or client representatives, when appointing design firms, could consider the DfOSH capability attributes and priority weights in their decision-making to ensure that the appointed firms have the required DfOSH capability.

- The DfOSH capability attributes could also be incorporated into OSH management schemes for construction procurement. For example, the British Standard Institute (2013) PAS 91:2013, which is commonly used for pre-qualification in UK would need updating to incorporate the DfOSH capability attributes among the criteria for selecting designers. In countries where such safety schemes for construction procurement are non-existent, the relevant government and/or industry bodies could develop them while incorporating the DfOSH capability attributes as criteria for designer selection. This would enable design firms to be selected based on the relevant OSH criteria.

\section{Policy}

- As previously mentioned, DfOSH is growing in prominence in the global construction sector as can be seen by the introduction of regulations related to DfOSH in several countries e.g. Singapore and Australia. Such regulations and/or their associated codes of practice or guidance documents would need to highlight the significance of designer capability and its composing attributes as found by this study.

- Specifically in the UK and other European countries where the European Council Directive 92/57/EEC have been adapted, the existing DfOSH related legislation and associated guidance are not expansive in their explanation of the constituents of organisational capability or criteria for ascertaining the suitability/competence of various duty-holders including designers. This could create uncertainty and lack of 
clarity amongst the design community and industry as a whole. Consequently, it would be useful for future updates of the legislation and/or associated guidance to acknowledge the DfOSH capability attributes identified by this study to provide clearer guidance on design firms' organisational capability.

\section{Implications for research}

- Beyond the specific domain of DfOSH in construction, this research has also shown that attributes/criteria that determine organisational capability in the fulfilment of a function can have varying weights of importance. However, in several studies within construction engineering and management and beyond, this aspect of organisational capability is often not considered or overlooked (e.g. Hillson, 2003; Strutt et al., 2006; Succar, 2009), thus leading to a potentially erroneous assumption that capability attributes/criteria have the same weight of importance. Learning from the findings and methodological approach in this studies, it would be useful for research regarding organisational capability in the fulfilment of a function to go beyond identifying capability attributes/criteria to establish the relative priority of such attributes/criteria.

- The aforementioned UK CDM regulations, which has been the main stimuli for DfOSH implementation in UK, introduced in its latest version (i.e. CDM 2015) the new role of "principal designer" - a designer (an organisation or individual) appointed by the client in projects involving more than one contractor (HSE, 2015). The principal designer is expected to plan, manage, monitor and coordinate health and safety in the preconstruction phase of a project, and this includes: identifying, eliminating or controlling foreseeable risks; and ensuring that designers carry out their duties. While the insights offered by this study could bear relevance to developing understanding regarding principal designer organisational capability under the CDM 2015, it would be useful for further research to be undertaken to specifically explore what constitutes organisational capability for a principal designer organisation.

\section{References}

Aires, M. D. M., Gamez, M. C. R., and Gibb, A. G. F. (2010), "Prevention through design: The European directives on construction workplace accidents", Safety Science, 48(2), pp. 248-258.

Ameyaw, E. E., Hu, Y., Shan, M., Chan, A. P. C. and Le, Y. (2016), “Application of Delphi method in construction engineering and management research: A quantitative perspective", Journal of Civil Engineering and Management, 22(8), pp. 991-1000.

Braimah, N. (2008), An investigation into the use of construction delay and disruption analysis methodologies, $\mathrm{PhD}$ thesis, University of Wolverhampton.

Behm, M. (2005), "Linking construction fatalities to the design for construction safety concept", Safety Science, 43(8), pp. 589-611.

Behm, M. (2012), "Safe design suggestions for vegetated roofs", Journal of Construction Engineering and Management, 138 (2), pp. 999 - 1003.

Behm, M., Culvenor, J. and Dixon, G. (2014), "Development of safe design thinking among engineering students", Safety Science, 63, pp. 1-7.

British Standard Institute (2013), Construction prequalification questionnaires, PAS91: 2013, BSI, London.

Bureau of Labor Statistics (2018), "Census of fatal occupational injuries charts, 1992-2017 (final data)", available at: https://www.bls.gov/iif/oshcfoi1.htm (accessed 8 January 2019).

CITB (2014), Competence in Construction, Pye Tait Consulting, Harrogate. 
Court, P.F., Pasquire, C.L., Gibb, A.G.F. and Bower, D. (2009), "Modular assembly with postponement to improve health, safety and productivity in construction", $A S C E$ Structural Design and Construction, 14(2), pp.81-89.

Dalkey, N., Brown, B. and Cochran, S. (1970), "Use of self-ratings to improve group estimates", Technological Forecasting, 1(3), pp. 283-291.

Field, A. (2013), Discovering statistics using SPSS, 4th ed., Sage Publications Ltd, London.

Foster, P. and Hoult, S. (2013), "The safety journey: Using a safety maturity model for safety planning and assurance in the UK coal mining industry", Minerals, 3(1), pp. 59-72.

Gambatese, J., Behm, M., Hinze, J. (2005), "Viability of designing for construction worker safety", Journal of Construction Engineering and Management, 131 (9), pp.1029-1036.

Gambatese, J., Hinze, J., and Haas, C. (1997), “Tool to design for construction worker safety", Journal of Architectural Engineering, 3(1), pp. 32-41.

Gibb, A.G.F., Haslam, R.A., Gyi, D.E., Hide, S. and Duff, R. (2006), "What causes accidents?", Proceedings of ICE-Civil Engineering, 159 (6), pp. 46-50.

Gibb, A.G.F., Lingard, H., Behm, M. and Cooke, T. (2014), "Construction accident causality: learning from different countries and differing consequences", Construction Management and Economics, 32 (5), pp. 446-459.

Hadikusumo, B. and Rowlinson, S. (2004), "Capturing safety knowledge using design-forsafety-process tool”, Journal of Construction Engineering Management, 130(2), pp. 281289.

Hadi-Vencheh, A. and Niazi-Motlagh, M. (2011), "An improved voting analytic hierarchy process-data envelopment analysis methodology for suppliers selection", International Journal of Computer Integrated Manufacturing, 24(3), pp. 189-197

Hallowell, M. R. and Gambatese, J. A. (2010), "Qualitative research: Application of the Delphi method to CEM research", Journal of Construction Engineering and Management, 136(1), pp. 99-107.

Hallowell, M.R. and Hansen, D. (2016), "Measuring and improving designer hazard recognition skill: Critical competency to enable prevention through design", Safety Science, 82(2016), pp.254-263.

Haslam, R.A., Hide, S. A., Gibb, A.G.F., Gyi, D.E., Pavitt, T., Atkinson, S. and Duff, A.R. (2005), "Contributing factors in construction accidents", Applied Ergonomics, 36(4), pp. 401-415.

Hayne, G., Kumar, B. and Hare, B. (2017), "Design hazard identification and the link to site experience", Proceedings of the Institution of Civil Engineers - Management, Procurement and Law, 170. pp. 1-10.

Hillson, D. (2003), "Assessing organisational project management capability", Journal of Facilities Management, 2 (3), pp. 298 - 311.

HSE (2000), Keil Centre Offshore Technology Report 2000-049: Safety Culture Maturity Model, HSE Books, London, UK.

HSE (2014), "Health and safety in construction in Great Britain, 2014". available at: http://www.cirruspurchasing.co.uk/constructionRIDDOR2015.pdf (accessed 20 July 2016).

HSE (2015), Managing health and safety in construction - Construction (Design and Management) Regulations 2015 Guidance L153", HSE Books, Norwich, UK.

HSE (2018), "Construction statistics in Great Britain, 2018”, available at: http://www.hse.gov.uk/statistics/industry/construction.pdf (accessed 8 January 2019).

Jensen. C. (2015), "DFMA and the A453 Road Widening project: A new approach to bridge construction", available at: https://www.ice.org.uk/knowledge-and-resources/casestudies/dfma-a453-road-widening-new-approach-bridge (accessed 13 March 2018).

$\mathrm{Ku}, \mathrm{K}$. and Mills, T. (2010), "Research needs for building information modeling for 
construction safety", in Proceedings of the Associated Schools of Construction 46th Annual Conference, April 7-10, Boston, Massachusetts, Associated Schools of Construction.

Liu, F-H. F. and Hai, H. L. (2005), "The voting analytic hierarchy process method for selecting supplier", International Journal of Production Economics, 97(3), pp. 308-317.

López-Arquillos, A., Rubio-Romero, J. C., and Martinez-Aires, M. D. (2015), "Prevention through design (PtD). The importance of the concept in engineering and architecture university courses", Safety Science, 73, pp. 8-14.

Mahamadu, A.-M., Mahdjoubi, L., Booth, C. and Fewings, P. (2015), "Integrated delivery of quality, safety and environment through road sector procurement: The case of public sector agencies in Ghana", Journal of Construction in Developing Countries, 20 (1). pp. $1-24$.

Manu, P., Ankrah, N., Proverbs, D. and Suresh, S. (2010), "An approach for determining the extent of contribution of construction project features to accident causation", Safety Science, 48 (6), pp. 687-692.

Manu, P., Ankrah, N., Proverbs, D. and Suresh, S. (2012), "Investigating the multi-causal and complex nature of the accident causal influence of construction project features", Accident Analysis and Prevention, 48, pp. 126-133.

Manu, P., Ankrah, N., Proverbs, D. and Suresh, S. (2014), "The health and safety impact of construction project features", Engineering Construction and Architectural Management, 21(1), pp. 65 - 93.

Manu, P., Mahdjoubi, L., Gibb, A., and Behm, M. (2017), "Briefing: New tool will help civil engineers meet CDM requirements to design for safety", Proceedings of the Institution of Civil Engineers - Civil Engineering, 170 (CE2), p. 55.

Martínez-Airesa, M.D., López-Alonsob, M. and Martínez-Rojasc, M. (2018), "Building information modeling and safety management: A systematic review", Safety Science, 101, pp. 11-18.

Öney-Yazıc1, E. and Dulaimi, M. F. (2015), "Understanding designing for construction safety: the interaction between confidence and attitude of designers and safety culture", Architectural Engineering and Design Management, 11(5), pp. 325-337.

Saaty, T. L. (1980), The analytic hierarchy process, McGraw- Hill, New York.

Saurin, T. A., and Formoso, C. T. (2008), "Guidelines for considering construction safety requirements in the design process", in Hinze, J., Bohner, S., and Lew, J. (eds.), Proceedings of CIB W099 International Conference, March 9-11, 2008, CIB, Gainesville, Florida.

Schulte, P. A., Rinehart, R., Okun, A., Geraci, C. L., \& Heidel, D. S. (2008), "National prevention through design (PtD) initiative", Journal of Safety Research, 39(2), pp. 115121.

Siegel, S., and Castellan Jr., J. N. (1988), Nonparametric statistics for the behavioural sciences, 2nd edn, McGraw-Hill, New York.

Skan, D. (2015), "Recognising health hazards in construction", in McAleenan, C. and Oloke, D. (eds.), ICE manual of health and safety in construction, $2^{\text {nd }}$ edn., Thomas Telford Limited, London.

Skulmoski, G. J., Hartman, F. T. and Krahn, J. (2007), "The Delphi method for graduate research", Journal of Information Technology Education, 6, pp. 1-21.

Software Engineering Institute (2011), Capability maturity model integration (CMMI), Software Engineering Institute, Pittsburgh.

Strutt, J. E., Sharp, J. V., Terry, E. and Miles, R. (2006), "Capability maturity models for offshore organisational management", Environment International, 32(8), pp. 1094-1105.

Succar, B. (2009), "Building information modelling maturity matrix", in Underwood, J. and 
Isikdag, U. (Eds.), Handbook of Research on Building Information Modelling and Construction Informatics: Concepts and Technologies, ISR, Hersey.

Teo, A., Ofori, G., Tjandra, I., and Kim, H. (2016), "Design for safety: theoretical framework of the safety aspect of BIM system to determine the safety index", Construction Economics and Building, 16(4), pp. 1-18.

Toh, Y. Z., Goh, Y. M. and Guo, B. H. W. (2016), "Knowledge, attitude, and practice of design for safety: multiple stakeholders in the Singapore Construction Industry", Journal of Construction Engineering and Management, 143 (5), pp. 1-11.

Tomlison, C.M. (1994), "Notes on the techniques adopted for knowledge elicitation", Systems research and Information Science, 6(4), pp. 179-185.

Tymvious, N. and Gambatese, J. (2016), "Direction for generating interest for design for construction worker safety- A Delphi study", Journal of Construction Engineering Management, 142(8), pp. 1-11.

Waehrer, G. M., Dong, X.S., Miller, T., Haile, E. and Men, Y. (2007), "Costs of occupational injuries in construction in the United States", Accident Analysis and Prevention, 39(6), pp. 1258-1266.

Zaira, M. M and Hadikusumo, B. H.W. (2017), "Structural equation model of integrated safety intervention practices affecting the safety behaviour of workers in the construction industry”, Safety Science, 98, pp. 124-135. 


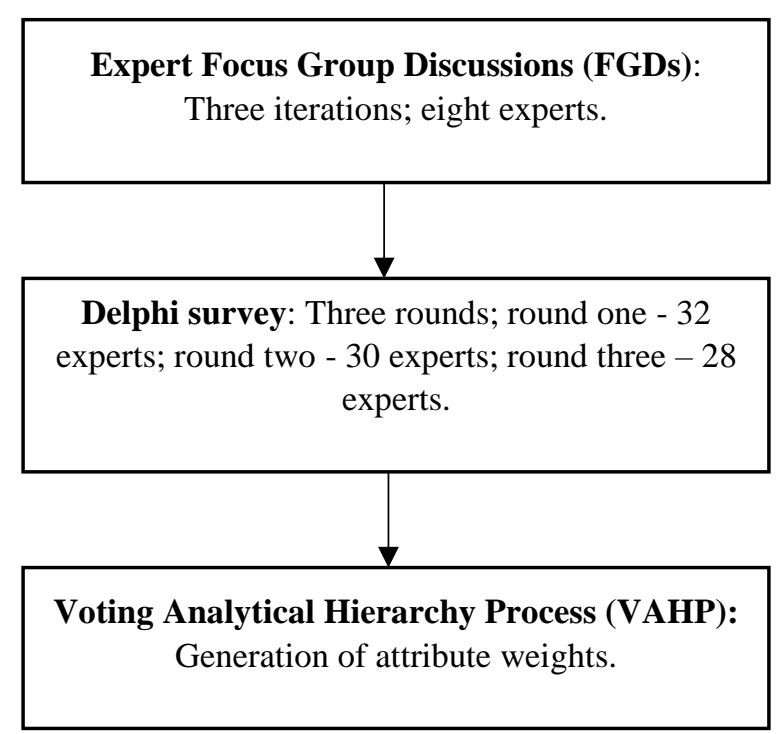

Figure 1: Overview of research process 
Table 1: Characteristics of the applied Delphi process

\begin{tabular}{|c|c|c|}
\hline Characteristic & Requirements offered in literature & Applied characteristic \\
\hline Expertise & $\begin{array}{l}\text { - Knowledge and experience with the } \\
\text { issues under investigation; capacity and } \\
\text { willingness to participate (Hallowell and } \\
\text { Gambatese, 2010; Ameyaw et al., 2016). } \\
\text { - Years of professional experience in the } \\
\text { construction industry; academic } \\
\text { qualification and professional } \\
\text { qualification (Hallowell and Gambatese, } \\
\text { 2010; Ameyaw et al., 2016) }\end{array}$ & $\begin{array}{l}\text { - Participant's professional role must be } \\
\text { related to architectural/engineering } \\
\text { design, designing for OSH, OSH } \\
\text { management, and/or selection of design } \\
\text { firms. } \\
\text { - A minimum of five years of experience } \\
\text { in professional role and a minimum of } 10 \\
\text { years of experience in construction. }\end{array}$ \\
\hline $\begin{array}{l}\text { Number of } \\
\text { panellists }\end{array}$ & $\begin{array}{l}\text { - Minimum of eight (Hallowell and } \\
\text { Gambatese, 2010) } \\
\text { - Minimum of } 10 \text { (Skulmoski et al., 2007) } \\
\text { - Most commonly used panel sizes in } \\
\text { construction engineering and } \\
\text { management (CEM) studies are } 8 \text { to } 20 \\
\text { and } 21 \text { to } 30 \text { (Ameyaw et al., 2016) }\end{array}$ & 28 to 32 experts participated in the study. \\
\hline $\begin{array}{l}\text { Number of } \\
\text { rounds }\end{array}$ & $\begin{array}{l}\text { Three rounds (Hallowell and Gambatese, } \\
\text { 2010) with round one usually being a } \\
\text { preliminary round for identification of } \\
\text { factors/items. }\end{array}$ & $\begin{array}{l}\text { Three rounds. A preliminary round to } \\
\text { identify factors (in this case the DfOSH } \\
\text { capability attributes) was not needed as } \\
\text { the attributes had already been identified } \\
\text { from the FGDs. }\end{array}$ \\
\hline Feedback & $\begin{array}{l}\text { - Mean (Ameyaw et al., 2016). } \\
\text { - Median (Hallowell and Gambatese, } \\
\text { 2010; Ameyaw et al., 2016). }\end{array}$ & $\begin{array}{l}\text { Median was used due to the used of } \\
\text { ordinal scale (i.e. ranking of attributes) in } \\
\text { the Delphi questionnaire. }\end{array}$ \\
\hline $\begin{array}{l}\text { Measure of } \\
\text { consensus/agree } \\
\text { ment }\end{array}$ & $\begin{array}{l}\text { - Standard deviation (Ameyaw et al., } \\
\text { 2016) } \\
\text { - Absolute deviation (Hallowel and } \\
\text { Gambatesse, 2010; Ameyaw et al., } \\
\text { 2016). } \\
\text { - Kendall's coefficient of concordance }(W) \\
\text { (Ameyaw et al., 2016). }\end{array}$ & $\begin{array}{l}\text { - Kendall's } W \text { was used due to the use of } \\
\text { ranked responses (i.e. ordinal data). } \\
\text { - Wilcoxon signed rank test (Z) was used } \\
\text { to ascertain saturation. This is a non- } \\
\text { parametric test used to ascertain } \\
\text { differences between two sets of scores } \\
\text { from the same participants (Field, 2013), } \\
\text { thus its suitability for investigating if } \\
\text { there are any significant changes in } \\
\text { participants scores from one time point } \\
\text { (e.g. a Delphi round) to another. }\end{array}$ \\
\hline
\end{tabular}


Table 2: Coefficient weights

\begin{tabular}{c|c}
\hline Number of criteria/sub-criteria (positions) & Coefficient $\left(\mathrm{w}_{\mathrm{s}}\right)$ \\
\hline \multirow{2}{*}{2} & $w_{1}=0.6667$ \\
& $w_{2}=0.3333$ \\
\hline \multirow{2}{*}{3} & $w_{1}=0.5455$ \\
& $w_{2}=0.2727$ \\
& $w_{3}=0.1818$ \\
\hline \multirow{2}{*}{4} & $w_{1}=0.4800$ \\
& $w_{2}=0.2400$ \\
& $w_{3}=0.1600$ \\
& $w_{4}=0.1200$ \\
\hline \multirow{2}{*}{6} & $w_{1}=0.4082$ \\
& $w_{2}=0.2041$ \\
& $w_{3}=0.1361$ \\
& $w_{4}=0.1020$ \\
& $w_{5}=0.0816$ \\
& $w_{6}=0.0680$ \\
\hline
\end{tabular}


Table 3: Focus group discussion experts.

\begin{tabular}{|c|c|c|c|}
\hline Professional role & $\begin{array}{c}\text { Experience in } \\
\text { professional role }\end{array}$ & $\begin{array}{l}\text { Experience in } \\
\text { construction }\end{array}$ & $\begin{array}{l}\text { Professional body } \\
\text { affiliation/qualifications }\end{array}$ \\
\hline Senior design manager & 12 years & 30 years & CIOB \\
\hline Architect & $\begin{array}{l}31 \text { years as } \\
\text { architect }\end{array}$ & 31 years as architect & RIBA \\
\hline OSH Professional & $\begin{array}{l}5 \text { years in current } \\
\text { role, } 7 \text { years as } \\
\text { safety professional, } \\
20 \text { years as design } \\
\text { manager. }\end{array}$ & 17 years & IOSH \\
\hline OSH consultant & 10 years & $\begin{array}{l}15 \text { years (including } \\
\text { facilities } \\
\text { management) }\end{array}$ & IOSH, IIRSM \\
\hline $\begin{array}{l}\text { Civil/structural engineer and } \\
\text { CDM specialist }\end{array}$ & 28 years & 28 years & ICE, IStructE, APS \\
\hline $\begin{array}{l}\text { Civil engineer and OHS } \\
\text { Professional }\end{array}$ & 27 years in $\mathrm{OHS}$ & 40 years & ICE, IOSH. \\
\hline Senior quantity surveyor & 20 years & 28 years & RICS \\
\hline Project manager & $\begin{array}{l}10 \text { years as quantity } \\
\text { surveyor and } 20 \\
\text { years as project } \\
\text { manager }\end{array}$ & 33 years & RICS, APM \\
\hline
\end{tabular}

Notes:

APS = Association for Project Safety; APM = Association for Project Management; CDM = Construction Design and Management Regulations; $\mathrm{CIOB}=$ Chartered Institute of Building; ICE $=$ Institution of Civil Engineers; IIRSM = International Institute of Risk and Safety Management; IOSH = The Institution of Occupational Safety and Health; IStructE = Institution of Structural Engineers; OSH = Occupational Safety and Health; RIBA = Royal Institute of British Architects; RICS = Royal Institution of Chartered Surveyors 
Table 4: Professional profile of Delphi experts

\begin{tabular}{|c|c|c|c|c|}
\hline Professional role & Experience in professional role & $\begin{array}{l}\text { Experience in } \\
\text { construction }\end{array}$ & $\begin{array}{c}\text { Professional } \\
\text { affiliations/qualifications }\end{array}$ & $\begin{array}{c}\text { Educational } \\
\text { Qualifications }\end{array}$ \\
\hline CDM professional & 23 years & 38 years & $\begin{array}{l}\text { CEng, ICE, IStructE, } \\
\text { CIOB, APS and IOSH }\end{array}$ & BSc, Diploma \\
\hline OSH strategy manager & $\begin{array}{l}10 \text { years as site-based } \\
\text { construction safety management, } \\
3 \text { years OSH training delivery, } \\
\text { and } 4 \text { years OSH strategy } \\
\text { manager. }\end{array}$ & 17 years & IOSH & NEBOSH Diploma \\
\hline Associate - Rail and OSH advisor & $\begin{array}{l}20 \text { years as a civil engineer and } 7 \\
\text { years as an OSH Advisor. }\end{array}$ & 20 years & CEng, IOSH & MSc, BEng \\
\hline Architect & $\begin{array}{l}15 \text { as architect and construction } \\
\text { OSH professional }\end{array}$ & 15 years & CABE, APS & BArch \\
\hline River and coastal engineer plus principal designer & 23 years & 30 years & CEng, ICE, APS & BEng \\
\hline Academic and civil engineer & $\begin{array}{l}32 \text { years as Civil engineer, } 7 \text { years } \\
\text { as lecturer and } 22 \text { years as OSH } \\
\text { consultant }\end{array}$ & 39 years & ICE & $\mathrm{PhD}$ \\
\hline Architect/principal designer & 31 years as architect & $\begin{array}{l}31 \text { years as } \\
\text { architect }\end{array}$ & RIBA & $\mathrm{MSc}, \mathrm{BA}$ \\
\hline OSH professional & 17 years & 20 years & IOSH & MSc \\
\hline OSH professional & 17 years & 25 years & IOSH & NEBOSH Diploma \\
\hline Civil/structural engineer & 10 years & 25 years & ICE, CIOB & PhD, MSc, BEng \\
\hline Civil/structural engineer & 44 years & 46 years & $\begin{array}{l}\text { CEng, IStructE, ICE, } \\
\text { APS }\end{array}$ & $\mathrm{BSc}$ \\
\hline Regional design manager & 27 years as design manager & 41 years & & Higher Certificate \\
\hline OSH professional & 12 years & 15 years & IOSH, IIRSM, APS & $\mathrm{BSc}$ \\
\hline Senior OSH consultant & $\begin{array}{l}6 \text { years OSH inspector (for } \\
\text { construction), } 5 \text { years as design } \\
\text { manager, and } 11 \text { years as } \\
\text { consultant CDM projects }\end{array}$ & 22 years & IIRSM & Postgraduate Diploma \\
\hline Architect & 15 years & 24 years & RIBA & BA, Diploma \\
\hline
\end{tabular}




\begin{tabular}{|c|c|c|c|c|}
\hline OSH consultant & 6.5 years & 10 years & IOSH & $\mathrm{BSc}$ \\
\hline Building surveyor/engineer \& designer & 30 years & 25 years & $\begin{array}{l}\text { RICS, CABE, CIOB, } \\
\text { APS }\end{array}$ & MSc, Diploma, HNC \\
\hline Design project manager & $\begin{array}{l}20 \text { years as a designer/project } \\
\text { manager, } 5 \text { years as OSH } \\
\text { manager }\end{array}$ & 42 years & CEng, ICE, IOSH, APS & $\mathrm{BSc}$ \\
\hline Principal engineer and safety advisor & $\begin{array}{l}6 \text { years as senior engineer and } 5 \\
\text { years OSH advisor }\end{array}$ & 19 years & CEng, ICE & MEng \\
\hline OSH consultant & 10 years as OSH professional & $\begin{array}{l}15 \text { years } \\
\text { (including } \\
\text { facilities } \\
\text { management) }\end{array}$ & IOSH, IIRSM & $\begin{array}{l}\text { MSc, BSc, NEBOSH } \\
\text { Diploma }\end{array}$ \\
\hline Senior group OSH manager & 36 years as a OSH professional & 36 years & $\mathrm{IOSH}$ & BSc Hons \\
\hline Architect & 26 years & 29 years & RIBA & BA, Diploma \\
\hline Architect and principal designer lead & 25 years & 35 years & RIBA, APS & BA, Diploma \\
\hline Head of contract services & Over 20years & 36 years & CIOB, APS & MSc \\
\hline Health and safety adviser & $\begin{array}{l}16 \text { years as OSH } \\
\text { adviser/consultant }\end{array}$ & 16 years & IOSH & Postgraduate Diploma \\
\hline Health and safety professional & $\begin{array}{l}5 \text { years as OSH manager, } 7 \text { years } \\
\text { as safety professional, } 20 \text { years as } \\
\text { design manager }\end{array}$ & 17 years & IOSH & HND, NVQ \\
\hline Civil/structural engineer, CDM specialist. & 28 years & 28 years & ICE, IStructE, APS & BEng \\
\hline Head of engineering - infrastructure projects & $\begin{array}{l}3.5 \text { years as head of engineering } \\
\text { and over } 20 \text { years in engineering } \\
\text { design and construction. }\end{array}$ & 27 years & CEng, ICE & MSc, BEng \\
\hline OSH professional & 41 years & 41 years & IOSH, APS, CIOB & $\mathrm{MSc}$ \\
\hline Architect and principal designer & $\begin{array}{l}35 \text { years as architect and } 20 \text { years } \\
\text { as CDM duty-holder }\end{array}$ & 35 years & ARB, APS & BSc, BArch \\
\hline Project manager & 18 years as project manager & 25 years & ICIOB & $\mathrm{BSc}$ \\
\hline Pre-construction manager & 12 as years as a technical leader & 45 years & & $\mathrm{HNC}$ \\
\hline
\end{tabular}


Notes:

APS $=$ Association for Project Safety ARB $=$ Architects Registration Board BA = Bachelor of Arts; BArch = Bachelor of Architecture; BEng = Bachelor of

Engineering; $\mathrm{BSc}=$ Bachelor of Science $\mathrm{CABE}=$ Chartered Association of Building Engineers; $\mathrm{CDM}=$ Construction Design and Management Regulations; CEng

$=$ Chartered Engineer; $\mathrm{CIOB}=$ Chartered Institute of Building; HNC = Higher National Certificate; HND = Higher National Diploma; ICE = Institution of Civil

Engineers; IIRSM = International Institute of Risk and Safety Management; IOSH = The Institution of Occupational Safety and Health; IStructE = Institution of

Structural Engineers; MEng = Master of Engineering; MSc = Master of Science; NVQ = National Vocation Qualification; OSH = Occupational Safety and Health; RIBA = Royal Institute of British Architects; RICS = Royal Institution of Chartered Surveyors. 
Table 5: DfOSH capability attributes

\begin{tabular}{|c|c|c|}
\hline Thematic category & Attributes & Example of attribute indicators \\
\hline \multirow{6}{*}{$\begin{array}{l}\text { Competence i.e. the competence of organisation's } \\
\text { design staff in respect of DfOSH. }\end{array}$} & DfOSH skills of design staff. & CVs of design staff and senior managers. \\
\hline & DfOSH knowledge of design staff. & Design staff qualifications. \\
\hline & DfOSH experience of design staff. & CVs of design staff and senior managers. \\
\hline & $\begin{array}{l}\text { Access of design staff to in-house or external competent } \\
\text { OSH, construction/constructability and maintainability } \\
\text { advice. }\end{array}$ & In-house competent personnel. \\
\hline & $\begin{array}{l}\text { Clear definition of roles for design staff at various levels } \\
\text { as well as the recruitment of design staff into the } \\
\text { appropriate roles. }\end{array}$ & $\begin{array}{l}\text { Design staff role description at various levels } \\
\text { e.g. graduate designer to senior designer. }\end{array}$ \\
\hline & $\begin{array}{l}\text { DfOSH continuous professional development (CPD) } \\
\text { training for design staff. }\end{array}$ & CPD training records for design staff. \\
\hline \multirow{3}{*}{$\begin{array}{l}\text { Strategy i.e. the consideration of DfOSH in } \\
\text { organisation's vision as well as the top } \\
\text { management support for DfOSH. }\end{array}$} & Organisation's policy in relation to DfOSH. & Company policy. \\
\hline & Organisation's top management commitment to DfOSH. & $\begin{array}{l}\text { A senior manager acting as DfOSH champion } \\
\text { within organisation. }\end{array}$ \\
\hline & $\begin{array}{l}\text { DfOSH research and innovation i.e. organisation's } \\
\text { investment into, conduct of, or exploitation of existing } \\
\text { research to enhance DfOSH, as well as organisation's } \\
\text { ability to be creative in implementing DfOSH. }\end{array}$ & Research and development budget. \\
\hline *Corporate experience & $\begin{array}{l}\text { Corporate experience i.e. organisation's experience in } \\
\text { implementing DfOSH on projects. }\end{array}$ & Portfolio of past projects. \\
\hline \multirow{4}{*}{$\begin{array}{l}\text { Systems i.e. organisation's systems, processes and } \\
\text { procedures required for DfOSH. }\end{array}$} & $\begin{array}{l}\text { Design quality management i.e. systems, processes and } \\
\text { procedures for design quality review to capture and rectify } \\
\text { errors and to ensure conformance of design to proposed } \\
\text { DfOSH solutions. }\end{array}$ & $\begin{array}{l}\text { Certification to ISO } 9001 \text { Quality Management } \\
\text { System. }\end{array}$ \\
\hline & $\begin{array}{l}\text { Design risk management i.e. systems, processes and } \\
\text { procedures for identification and mitigation of OSH } \\
\text { hazards in design as part of design workflow. }\end{array}$ & Design risk register. \\
\hline & $\begin{array}{l}\text { Project review i.e. systems, processes and procedures for } \\
\text { capturing lessons learnt in order to facilitate future } \\
\text { improvements. }\end{array}$ & Participation in post-occupancy evaluations. \\
\hline & $\begin{array}{l}\text { Systems, processes, and procedures for ensuring } \\
\text { appointment of competent outsourced/subcontracted } \\
\text { designers/consultants. }\end{array}$ & Company's own prequalification arrangements. \\
\hline
\end{tabular}


Infrastructure i.e. organisation's physical,

information and communication technology (ICT) resources required for DfOSH.

Collaboration

firm (as a unit) to collaborate with other organisations on

a project to implement DfOSH.

ICT resources i.e. computing and ICT facilities (including hardware and software) that support DfOSH and

Intra-organisational collaboration i.e. the ability of variou

design units/sections/departments within organisation to

collaborate to implement DfOSH on projects.
Workstations and workspace.

workspace/workplace environment, and

equipment/materials that support design and DfOSH. communication or sharing of design information.

meetings.

Participation in routine project design meetings.

Notes: * "Corporate experience" is a stand-alone attribute that constituted its own thematic category. 
Table 6: Summary of Delphi results

\begin{tabular}{|c|c|c|c|c|c|c|c|c|c|c|c|c|}
\hline \multirow[t]{2}{*}{ Thematic category/attributes } & \multicolumn{4}{|c|}{ Round $1(\mathrm{~N}=32)$} & \multicolumn{4}{|c|}{ Round $2(\mathrm{~N}=30)$} & \multicolumn{4}{|c|}{ Round $3(\mathrm{~N}=28)$} \\
\hline & Median & $\begin{array}{c}\text { Mean } \\
\text { rank }\end{array}$ & $\begin{array}{l}\text { Kendall's } \\
\text { W }\end{array}$ & Sig. & Median & $\begin{array}{c}\text { Mean } \\
\text { rank }\end{array}$ & $\begin{array}{l}\text { Kendall's } \\
\text { W }\end{array}$ & Sig. & Median & $\begin{array}{c}\text { Mean } \\
\text { rank }\end{array}$ & $\begin{array}{l}\text { Kendall's } \\
\text { W }\end{array}$ & Sig. \\
\hline \multicolumn{13}{|l|}{ Thematic category of attributes } \\
\hline Competence & 1 & 1.58 & \multirow{6}{*}{0.434} & \multirow{6}{*}{0.000} & 1 & 1.35 & \multirow{6}{*}{0.602} & \multirow{6}{*}{0.000} & \multicolumn{4}{|c|}{ N/A } \\
\hline Strategy & 3 & 3.25 & & & 2.5 & 3.07 & & & \multicolumn{4}{|c|}{ N/A } \\
\hline *Corporate Experience & 3 & 3.22 & & & 2.5 & 2.8 & & & \multicolumn{3}{|c|}{ N/A } & \\
\hline Systems & 4 & 3.78 & & & 4 & 4.02 & & & \multicolumn{3}{|c|}{ N/A } & \\
\hline Infrastructure & 5 & 5.33 & & & 6 & 5.53 & & & \multicolumn{3}{|c|}{ N/A } & \\
\hline Collaboration & 4 & 3.84 & & & 4 & 4.23 & & & \multicolumn{3}{|c|}{ N/A } & \\
\hline \multicolumn{13}{|l|}{ Competence attributes } \\
\hline Skills & 2 & 2.8 & \multirow{6}{*}{0.349} & \multirow{6}{*}{0.000} & 2 & 2.57 & \multirow{6}{*}{0.462} & \multirow{6}{*}{0.000} & \multicolumn{4}{|c|}{ N/A } \\
\hline Knowledge & 2 & 2.44 & & & 2 & 2.33 & & & \multicolumn{4}{|c|}{ N/A } \\
\hline Experience & 1 & 2.47 & & & 1 & 2.3 & & & \multicolumn{4}{|c|}{ N/A } \\
\hline Access to competent advice & 4 & 3.91 & & & 4 & 4.22 & & & \multicolumn{4}{|c|}{ N/A } \\
\hline $\begin{array}{l}\text { Design staff role definition and } \\
\text { recruitment }\end{array}$ & 5 & 4.63 & & & 5 & 4.75 & & & \multicolumn{4}{|c|}{ N/A } \\
\hline Training & 5 & 4.77 & & & 5 & 4.83 & & & \multicolumn{4}{|c|}{ N/A } \\
\hline \multicolumn{13}{|l|}{ Strategy attributes } \\
\hline Policy & 2 & 2.39 & \multirow{3}{*}{0.415} & \multirow{3}{*}{0.000} & 2 & 2.25 & \multirow{3}{*}{0.493} & & & & J/A & \\
\hline Top management commitment & 1 & 1.27 & & & 1 & 1.22 & & 0.000 & & & J/A & \\
\hline Research and innovation & 3 & 2.34 & & & 3 & 2.53 & & & & & J/A & \\
\hline Systems attributes & & & & & & & & & & & & \\
\hline Design quality management & 2 & 2.42 & & & 2 & 2.48 & & & & & J/A & \\
\hline Design risk management & 1 & 1.33 & 0650 & $0 \Omega 0 \Omega$ & 1 & 1.17 & 0760 & $0 \Omega 0 \Omega$ & & & J/A & \\
\hline Project review & 2 & 2.44 & 0.650 & 0.000 & 2 & 2.48 & 0.162 & 0.000 & & & J/A & \\
\hline Outsourcing of designers/consultants & 4 & 3.81 & & & 4 & 3.87 & & & & & J/A & \\
\hline
\end{tabular}




\begin{tabular}{|c|c|c|c|c|c|c|c|c|c|c|c|c|}
\hline Infrastructure attributes & & & & & & & & & & & & \multirow[b]{2}{*}{0.239} \\
\hline $\begin{array}{l}\text { Physical work resources } \\
\text { ICT resources }\end{array}$ & $\begin{array}{l}1 \\
2\end{array}$ & $\begin{array}{l}1.42 \\
1.58\end{array}$ & 0.027 & 0.353 & $\begin{array}{l}1 \\
2\end{array}$ & $\begin{array}{l}1.38 \\
1.62\end{array}$ & 0.06 & 0.178 & $\begin{array}{l}1 \\
2\end{array}$ & $\begin{array}{l}1.39 \\
1.61\end{array}$ & 0.049 & \\
\hline \multicolumn{13}{|l|}{ Collaboration attributes } \\
\hline $\begin{array}{l}\text { Intra-organisational collaboration } \\
\text { Inter-organisational collaboration }\end{array}$ & $\begin{array}{l}1 \\
1\end{array}$ & $\begin{array}{l}1.53 \\
1.47\end{array}$ & 0.005 & 0.695 & $\begin{array}{l}1 \\
1\end{array}$ & $\begin{array}{l}1.55 \\
1.45\end{array}$ & 0.016 & 0.491 & $\begin{array}{l}1 \\
1\end{array}$ & $\begin{array}{l}1.54 \\
1.46\end{array}$ & 0.008 & 0.637 \\
\hline
\end{tabular}

Notes: N/A = not applicable

* "Corporate experience" is a stand-alone attribute that constituted its own thematic category. 


\begin{tabular}{|c|c|c|c|c|c|c|}
\hline \multicolumn{2}{|l|}{ Comparison } & $\mathrm{N}$ & $\begin{array}{l}\text { Mean } \\
\text { rank }\end{array}$ & $\begin{array}{l}\text { Sum of } \\
\text { ranks }\end{array}$ & $\begin{array}{l}\text { Wilcoxon } \\
\text { signed } \\
\text { ranks test } \\
\quad(\mathrm{Z})\end{array}$ & $\begin{array}{l}\text { Sig. }(2- \\
\text { tailed) }\end{array}$ \\
\hline $\begin{array}{l}\text { Physical resources (round 3) } \\
\text { - Physical resources (round } \\
\text { 2) }\end{array}$ & $\begin{array}{l}\text { Negative ranks } \\
\text { Positive ranks } \\
\text { Ties } \\
\text { Total }\end{array}$ & $\begin{array}{c}0^{\mathrm{a}} \\
0^{\mathrm{b}} \\
28^{\mathrm{c}} \\
28\end{array}$ & $\begin{array}{l}0 \\
0\end{array}$ & $\begin{array}{l}0 \\
0\end{array}$ & 0.000 & 1.000 \\
\hline $\begin{array}{l}\text { ICT resources (round 3) - } \\
\text { ICT resources (round 2) }\end{array}$ & $\begin{array}{l}\text { Negative ranks } \\
\text { Positive ranks } \\
\text { Ties } \\
\text { Total }\end{array}$ & $\begin{array}{c}5^{\mathrm{a}} \\
1^{\mathrm{b}} \\
22^{\mathrm{c}} \\
28 \\
\end{array}$ & $\begin{array}{l}3.5 \\
3.5\end{array}$ & $\begin{array}{c}17.5 \\
3.5\end{array}$ & -1.633 & 0.102 \\
\hline $\begin{array}{l}\text { Intra-collaboration (round } 3 \\
\text { - Intra-collaboration (round } \\
\text { 2) }\end{array}$ & $\begin{array}{l}\text { Negative ranks } \\
\text { Positive ranks } \\
\text { Ties } \\
\text { Total }\end{array}$ & $\begin{array}{c}1^{\mathrm{a}} \\
0^{\mathrm{b}} \\
27^{\mathrm{c}} \\
28\end{array}$ & $\begin{array}{l}1 \\
0\end{array}$ & $\begin{array}{l}1 \\
0\end{array}$ & -1 & 0.317 \\
\hline $\begin{array}{l}\text { Inter-collaboration (round } 3 \\
\text { - Inter-collaboration (round } \\
\text { 2) }\end{array}$ & $\begin{array}{l}\text { Negative ranks } \\
\text { Positive ranks } \\
\text { Ties } \\
\text { Total }\end{array}$ & $\begin{array}{c}0^{\mathrm{a}} \\
0^{\mathrm{b}} \\
28^{\mathrm{c}} \\
28 \\
\end{array}$ & $\begin{array}{l}0 \\
0\end{array}$ & $\begin{array}{l}0 \\
0\end{array}$ & $.000 \mathrm{~b}$ & 1 \\
\hline \multicolumn{7}{|c|}{$\begin{array}{l}a=\text { the count of the round } 3 \text { ranks that are less than the round } 2 \text { ranks } \\
b=\text { the count of the round } 3 \text { ranks that are greater than the round } 2 \text { ranks }\end{array}$} \\
\hline
\end{tabular}


Table 8: VAHP results by thematic category of attributes

\begin{tabular}{|c|c|c|c|}
\hline Thematic category/attributes & Weight & $\begin{array}{c}\text { Normalised } \\
\text { weight }\end{array}$ & $\begin{array}{c}\text { Rank within } \\
\text { category }\end{array}$ \\
\hline \multicolumn{4}{|l|}{ Thematic category of attributes } \\
\hline Competence & 11.0894 & 0.3493 & 1 \\
\hline Strategy & 5.6330 & 0.1774 & 2 \\
\hline *Corporate Experience & 5.5037 & 0.1733 & 3 \\
\hline Collaboration & 3.7688 & 0.1187 & 4 \\
\hline Systems & 3.4626 & 0.1091 & 5 \\
\hline Infrastructure & 2.2925 & 0.0722 & 6 \\
\hline \multicolumn{4}{|l|}{ Competence attributes } \\
\hline Experience & 8.9803 & 0.2525 & 1 \\
\hline Knowledge & 8.4156 & 0.2366 & 2 \\
\hline Skills & 7.5516 & 0.2123 & 3 \\
\hline Access to competent advice & 3.6530 & 0.1027 & 4 \\
\hline Design staff role definition and recruitment & 3.6258 & 0.1019 & 5 \\
\hline Training & 3.3399 & 0.0939 & 6 \\
\hline \multicolumn{4}{|l|}{ Systems attributes } \\
\hline Design risk management & 13.6800 & 0.4340 & 1 \\
\hline Project review & 7.2400 & 0.2297 & 2 \\
\hline Design quality management & 6.8000 & 0.2157 & 3 \\
\hline Outsourcing of designers/consultants & 3.8000 & 0.1206 & 4 \\
\hline \multicolumn{4}{|l|}{ Strategy attributes } \\
\hline Top management commitment & 15.1829 & 0.4985 & 1 \\
\hline Policy & 7.8175 & 0.2567 & 2 \\
\hline Research and innovation & 7.4542 & 0.2448 & 3 \\
\hline \multicolumn{4}{|l|}{ Infrastructure attributes } \\
\hline Physical work resources & 15.3336 & 0.5349 & 1 \\
\hline ICT resources & 13.3332 & 0.4651 & 2 \\
\hline \multicolumn{4}{|l|}{ Collaboration attributes } \\
\hline Inter-organisational collaboration & 16.0004 & 0.5106 & 1 \\
\hline Intra-organisational collaboration & 15.3336 & 0.4894 & 2 \\
\hline
\end{tabular}

Notes:* "Corporate experience" is a stand-alone attribute that constituted its own thematic category 
Table 9: VAHP results of global ranking of attributes

\begin{tabular}{l|c|c}
\hline Attributes & Global weight & Global rank \\
\hline Corporate experience & 0.1733 & 1 \\
Top management commitment & 0.0884 & 2 \\
Experience & 0.0882 & 3 \\
Knowledge & 0.0826 & 4 \\
Skills & 0.0742 & 5 \\
Inter-organisational collaboration & 0.0606 & 6 \\
Intra-organisational collaboration & 0.0581 & 7 \\
Design risk management & 0.0473 & 8 \\
Policy & 0.0455 & 9 \\
Research and innovation & 0.0434 & 10 \\
Physical work resources & 0.0386 & 11 \\
Access to competent advice & 0.0359 & 12 \\
Design staff role definition and recruitment & 0.0356 & 13 \\
ICT resources & 0.0336 & 14 \\
Training & 0.0328 & 15 \\
Project review & 0.0251 & 16 \\
Design quality management & 0.0235 & 17 \\
Outsourcing of designers/consultants & 0.0132 \\
\hline
\end{tabular}

